\title{
SYSTEMATIZATION OF THE TYPES OF FINANCIAL SECURITY OF A TRADE ENTERPRISE
}

\section{Butova Tetiana ${ }^{1}$}

DOI: https://doi.org/10.30525/978-9934-571-89-3_124

Determination of the ways to implement the financial security of a trade enterprise determines the identification of its types. At the same time, it becomes important to consider its types but not the content characteristics of the financial security itself. It represents a set of management decisions and actions defined in time and aimed at one or another format of the financial condition of the enterprise. The object of differentiation, in this case, is not the security system itself, but the means of its influence on the target result.

The consideration of financial security as a computational and analytical category directs the research to the determination of the consequences of the functioning of financial security as a management subsystem and is reflected in the financial state of the enterprise. Therefore, the differentiation of signs of the financial condition of the enterprise is a clear decision for the search of forms and methods for ensuring the financial security of the enterprise.

The type of financial security characterizes the degree of manifestation of the most significant signs of safeguarding the enterprise from non-fulfillment of financial obligations and ensuring the financing of target development. Specific differentiation of financial security is expedient to carry out by time points of evaluation and implementation. This allows distinguishing types of financial security that are subject to different criteria of assessment and have their own calculation methods.

In terms of analytical and managerial significance, there is operational, current, and perspective/strategic financial security of the enterprise. At the same time, perspective and strategic financial security are not identical concepts, but the latter, as a rule, is of a promising nature.

Operational and current financial securities differ not only in terms of time but also in terms of analytical purpose and method of quantification.

The analysis of research results shows that for the most part, scientists associate financial security with a certain financial condition of the enterprise. It is not taken into account that the financial condition is only a momentary characteristic. Therefore, achieving the desired financial status of the enterprise for a certain date is not a sign of the strength of its financial position in the current and, more importantly, promising periods.

The more important analytical object is current financial security. Its level to a lesser extent than operational security depends on temporary factors, which actions cannot be predicted. Therefore, the current financial situation that is observed over a certain period is the subject of planning and ongoing control, and the presence of a

${ }^{1}$ Kyiv National University of Trade and Economics, Ukraine 
trend in its changes serves as a sign of the need for management decisions and actions in relation to the current financial security system. Current financial security is subordinate and may vary within acceptable limits, which are determined by accepted managerial expediency and subjective perceptions of satisfactory security.

The operational type of current financial security entirely does not solve the problem of full security of the financial activity of the enterprise in the future. The strategic financial security serves to it, the formation of which differs not only in the complexity of management means of security but also in the awareness of its availability.

In the works of both Ukrainian and foreign scholars, the strategic nature of the research object is associated with the perspective of its development. So, in the work of H.V. Blakyta, when determining the essence of the category "business strategy", is considered as ".. a system of coordinated directions of its prospective development in the conditions of uncertainty, which are subject to certain long-term goals ..." [1, p. 19].

The point of view of such scientists as V.Ye. Rokhchyn, O.M. Vietrova, and O.V. Polianskyi, concerning the concept of strategic importance deserves attention as well. It characterizes "...... the ability of objects and subjects ... to maintain and (or) strengthen their positions in the global, multinational and local markets for a long time ..." [2, p. 58].

Overall, perspective is a necessary, but not a sufficient sign of strategic importance. In this approach, strategic importance and perspective are the categories that have synonymous content. In addition, the indication of the "duration" of the manifestation of the strategic importance requires substantiation and quantification

Investigating the strategic competitiveness of the enterprise R.A. Fatkhutdinov noted that it is "... a potential ability of an entity to compete in the future in specific markets, which is ensured by a reduction in the manifestation of strategic noncompetitive factors and an increase in the manifestation of the strategic exclusive competitive advantages of an entity (subject) on the basis of a comprehensive strategic diagnosis of ' object or subject, market parameters and competitors, strategy development..." [3, p. 34]. The author, along with the promising nature of strategic importance, pointed to its potential implementation format. This attitude points out precisely that the lack of appropriate potential is a prerequisite for its future development.

The strategic importance of the object is viewed under another angle by A.S. Shpanko, who connected it by "a sign of a market entity that demonstrates the presence of its key development opportunities, acquired through the rapid adaptation of the internal environment of operation to changes in the environment..." [4, p. 48]. Along with the need for the availability of "development opportunities", the author connects the potential nature of the strategic importance of the object with its adaptive ability the changing conditions of the environment. This is a very important refinement since the emergence of the strategic ideology in management is due to the impossibility of predicting changes in external nature.

Potential nature of the strategic importance has another indisputable feature - the potential nature of implementation. This means that the actual evidence of strategic 
financial security will be the appropriate financial position of the enterprise from a strategic perspective. The verification of this assumption can only be done after the fact. Therefore, the probable character of strategic financial security is its inherent feature, which has a differentiated level and depends on external and internal organizational conditions of management and management perception of the permissible level of risks.

Strategic financial security should be considered as the managerial potential of financial security of the company, which should be realized in the future. The main features of strategic financial security of an enterprise are the perspective, potential and probable nature of the implementation.

Thus, operational, current and strategic financial security represent different types of security for trade enterprises that have their content, analytical purpose and areas of managerial application.

\section{References:}

1. Blakyta Gh.V. (2010). Finansova strateghija torghoveljnykh pidpryjemstv: metodologhichni ta prykladni aspekty [Financial strategy of trading enterprises: methodological and applied aspects]. Kyiv: Kyiv National University of Trade and Economics. (in Ukrainian).

2. Rokhchin V.E., Vetrova E.N., Polyanskiy A.V. (2012). Upravlenie strategicheskoy konkurentosposobnost'yu promyshlennogo predpriyatiya na osnove razvitiya ego potentsiala [Management of strategic competitiveness of an industrial enterprise]. St. Petersburg: SPbGUEF. (in Russian).

3. Fatkhutdinov R. (2003). Strategicheskaya konkurentosposobnost' i ekonomika Rossii [Strategic competitiveness and the economy of Russia]. Society and economy, vol. 1, pp. 31-43.

4. Shpanko A. (2007). Pro sutnistj ponjattja "strateghichna konkurentospromozhnistj" [On the concept of "strategic competitiveness"]. Economy of Ukraine, vol. 6, pp. 45-49. 